\title{
Resource use Efficiency of Major Vegetables in Different Supply Chains in Eastern Dry Zone of Karnataka, India
}

\author{
R. Kiran ${ }^{1^{*}}$ and S.D. Sivakumar ${ }^{2}$ \\ ${ }^{1}$ Department of Agricultural Marketing, Cooperation and Business Management, \\ UAS, GKVK, Bengaluru, India \\ ${ }^{2}$ Director, Agri. Incubation Development, TNAU, Tamil Nadu, India \\ *Corresponding author
}

\begin{abstract}
A B S T R A C T
To study the resource productivity and efficiency in different vegetables, Cobb-Douglas type of production function was fitted. Two firms operating vegetable supply chains in

Keywords

Supply Chain,

Resource use,

Cobb-Douglas

Production Function

Article Info

Accepted:

18 May 2019

Available Online:

10 June 2019

Bengaluru rural district of Karnataka were identified, they were HOPCOMS (Cooperative) and Reliance fresh (Corporate). A sample of 180 farmers was selected using random sampling method and data was collected through personal interview method. Among the different vegetable supply chains major vegetables cultivated were identified by conducting a pilot survey in the study area, two major vegetables viz., tomato and beans were selected for the study based on maximum production and major vegetables procured. The results revealed that, the production function analysis for tomato, the elasticity coefficient for human labour and fertilizer in Reliance fresh, FYM and fertilizer in HOPCOMS, FYM, fertilizer and plant protection chemicals in traditional marketing channel were negative and the production function analysis for beans, the elasticity coefficient for FYM and fertilizer in Reliance fresh, human labour seed and FYM in HOPCOMS, FYM, fertilizer and plant protection chemicals in traditional marketing channel were negative, indicating over utilization of these resource. Efforts should be made through Raitha Samparka and Krishi Vigyana Kendr as to utilize farm resources rationally and to enhance productivity and profitability.
\end{abstract}

\section{Introduction}

In India vegetables occupied an area of 9.5 million hectares during 2017 with a total production of 167 million tonnes and an average productivity of 17.6 tonnes per hectare. Vegetable production registered a quantum jump of 66 per cent between 200102 and 2014-15. The area under vegetables during the last decade (2004-05 to 2014-15), increased from $6.7 \mathrm{M} \mathrm{Ha}$ to $9.5 \mathrm{M} \mathrm{Ha}$, production increased to $167.1 \mathrm{M}$ MT from 101.2 M MT, and productivity increased to 17.60 MT/ha from 15.1 MT/ha. Agriculture (including livestock) accounted for about 12 per cent of the national GDP. However, with around 50 percent of the population still dependent on agriculture for its livelihood, the sector continues to play a vital role through its multiplier impact on the economy 
(Directorate of Economics \& Statistics, 2017). The major vegetable crops grown in the country were potato, tomato, onion, brinjal, cabbage, cauliflower, peas, okra, chillies, beans, melons, etc. West Bengal was maintaining the lead in vegetable production in the country, contributing about 16 per cent to total production, while Uttar Pradesh produced almost 14 per cent of vegetables in the country.

The productivity of vegetables in Uttar Pradesh was as high as 21 tonnes per hectare against 19 tonnes per hectare in West Bengal. Other leading vegetable producing states were Bihar with an 8.6 per cent share, Madhya Pradesh with an 8.75 per cent share, Gujarat with a seven per cent share, Odisha with a six per cent share, Karnataka with a five per cent share and Tamil Nadu with a three per cent share. Amongst vegetables, potato was the most cultivated vegetable which accounted for 27 per cent of the total production of vegetables in the country, followed by onion (11 per cent), tomato (10 per cent), brinjal (7 per cent), cabbage ( 5 per cent), cauliflower ( 5 per cent) and peas ( 3 per cent).

\section{Materials and Methods}

Bangalore city was the hub of retail revolution having many fruit and vegetable markets operating from a long period of time. The retail formats have made Bangalore as their focal point of the managerial operations. Many vegetable growing districts surrounded the Bangalore city including Bangalore rural, Chikkaballapura Kolar and Ramanagara. Farmers growing their produce in these districts supplied their produce to local vegetable markets and retail formats established in Bangalore.

Since, this study was about vegetable supply chains, a preliminary visit was made to identify the vegetable supply chains in districts surrounding Bengaluru city, namely Bangalore rural, Chikkaballapura, Kolar and Ramanagara. Two firms operating vegetable supply chains were identified, they were The Horticultural Producers' Co-operative Marketing and Processing Society Ltd. [HOPCOMS, (Cooperative)] and Reliance Fresh (Corporate).

Among the four districts, Bengaluru rural district was selected because highest number of collection/procurement centres was present in this district. The modern retail outlets had opened procurement / collection centres in the Bengaluru rural district in order to take advantage of adequate supply of fresh and quality agricultural and horticultural produce.

In Bengaluru rural district Doddaballapura and Hosakote taluks were selected because both HOPCOMS and Reliance Fresh were operating collection/procurement centres in these taluks. Among the different vegetable supply chains, major vegetables identified by conducting a pilot survey in the study area, two major vegetables viz., tomato and beans were selected, based on maximum the production and major vegetables procured in the study area.

For the study, in each taluk 90 farmers were selected, of which 30 member-farmers of HOPCOMS, 30 registered farmers of Reliance fresh who are supplying vegetables to procurement / collection centres and 30 Traditional farmers, resulting in a total size of 180 farmers were randomly selected. To study resource productivity and efficiency in different vegetables, Cobb-Douglas type of production function was fitted. This was done with a view to determine the extent to which the important resources that have been quantified, explain the variability in the gross returns of the vegetables and to determine whether the resources were optimally used in these vegetable cultivation. 


\section{Functional Analysis}

Heady and Dillon (1963) indicated that the Cobb-Douglas type of production function has been the most popular of all possible algebraic forms in the farm firm analysis as it provides comparison, adequate fit, computational feasibility and sufficient degrees of freedom. They further indicated that Cobb-Douglas type of function has the greatest use in diagnostic analysis, reflecting the marginal productivities at mean levels of returns.

The general form of the function is $y=a x_{i}^{b i}$ where, ' $x_{i}$ ' is the variable resource measure, ' $y$ ' is the output, ' $a$ ' is a constant and 'bi' estimates the extent of relationship between $x_{i}$ and $\mathrm{y}$ and when $\mathrm{x}_{\mathrm{i}}$ is at different magnitudes. The ' $b$ ' coefficient also represents the elasticity of production in Cobb-Douglas production function analysis.

This type of function allows for either constant or increasing or decreasing returns to scale. It does not allow for total product curve embracing all the three simultaneously. Functions of the following form were fitted for major vegetables under different vegetable supply chains.

$\mathrm{Y}=\mathrm{ax}_{1}{ }^{\mathrm{b} 1} \cdot \mathrm{x}_{2}{ }^{\mathrm{b} 2} \cdot \mathrm{x}_{3}{ }^{\mathrm{b} 3} \ldots \ldots \ldots \ldots \ldots \ldots \mathrm{x}_{\mathrm{n}}{ }^{\mathrm{bn}}$

On linearization, it becomes

$\log \mathrm{Y}=\log \mathrm{a}+\mathrm{b}_{1} \log \mathrm{x}_{1}+\mathrm{b}_{2} \log \mathrm{x}_{2}+\mathrm{b}_{3} \log \mathrm{x}_{3}+$ ............. $b_{n} \log x_{n}$

Production function employed for cropping system as a whole is given below.

$\log (\mathrm{Y})=\log (\mathrm{a})+\mathrm{b}_{1} \log \left(\mathrm{x}_{1}\right)+\mathrm{b}_{2} \log \left(\mathrm{x}_{2}\right)+$ $\mathrm{b}_{3} \log \left(\mathrm{x}_{3}\right)+\mathrm{b}_{4} \log \left(\mathrm{x}_{4}\right)+\mathrm{b}_{5} \log \left(\mathrm{x}_{5}\right)+\mathrm{b}_{6} \log$ $\left(\mathrm{x}_{6}\right)+\mathrm{e}$

Where,

$$
\begin{aligned}
& \mathrm{Y}=\text { Gross returns in rupees/ acre } \\
& \mathrm{a}=\text { Intercept } \\
& \mathrm{x}_{1}=\text { Machine labour (rupees/acre) } \\
& \mathrm{x}_{2}=\text { Human labour (rupees/acre) } \\
& \mathrm{x}_{3}=\text { Seed (rupees/acre) } \\
& \mathrm{x}_{4}=\text { FYM (rupees/acre) } \\
& \mathrm{x}_{5}=\text { Fertilizer (rupees/acre) } \\
& \mathrm{x}_{6}=\text { PPC (rupees/acre) } \\
& \mathrm{b}_{\mathrm{i}}=\text { Elasticities of production }(\mathrm{i}=1 \text { to } 6) \\
& \mathrm{e}=\text { Error term }
\end{aligned}
$$

\section{Returns to scale}

The returns to scale were estimated directly by getting the sum of 'bi' coefficients.

The returns will be increasing, constant or diminishing based on whether value of summation of 'bi' is greater, equal or less than unity, respectively.

\section{Results and Discussion}

\section{Resource use efficiency of major vegetables in different supply chains}

Cobb-Douglas production function for tomato under different supply chains

The regression coefficients of various resources of tomato under different supply chains are presented in Table 1.

The production function analysis for tomato under Reliance fresh, HOPCOMS and traditional marketing channel indicated that 75, 68 and 64 per cent of the variation in gross returns was explained by the variables included in the production function.

The elasticity coefficients for machine labour and plant protection chemicals in Reliance Fresh; were statistically significant at 5 per cent level; In other words, every one per cent increase in machine labour the gross returns could increase to the tune of 0.052 per cent. 
Table.1 Cobb-Douglas production function for tomato under different supply chains

\begin{tabular}{|c|c|c|c|c|c|c|c|c|}
\hline \multirow[t]{2}{*}{ Sl. No } & \multirow[t]{2}{*}{ Particulars } & \multirow[t]{2}{*}{ Parameter } & \multicolumn{2}{|c|}{ Reliance Fresh } & \multicolumn{2}{|c|}{ HOPCOMS } & \multicolumn{2}{|c|}{ Traditional } \\
\hline & & & $\begin{array}{l}\text { Regression } \\
\text { coefficients }\end{array}$ & P-value & $\begin{array}{l}\text { Regression } \\
\text { coefficients }\end{array}$ & P-value & $\begin{array}{l}\text { Regression } \\
\text { coefficients }\end{array}$ & P-value \\
\hline 1 & Intercept & $\mathrm{a}$ & 12.289 & $1.76 \mathrm{E}-08$ & 2.330 & 0.471014 & 14.684 & $3.17 \mathrm{E}-12$ \\
\hline 3 & Human labour & b2 & -0.004 & 0.924821 & $0.137^{*}$ & 0.017562 & $0.098^{* *}$ & 0.004255 \\
\hline 4 & Seed & b3 & 0.338 & 0.819255 & $0.983^{*}$ & 0.016669 & $0.309^{*}$ & 0.014726 \\
\hline 5 & FYM & b4 & 0.422 & 0.933016 & -0.031 & 0.281983 & -0.029 & 0.344812 \\
\hline 7 & PPC & b6 & $0.098^{*}$ & 0.040619 & $0.134^{* *}$ & 0.002526 & -0.051 & 0.147252 \\
\hline \multicolumn{3}{|c|}{$\mathbf{R}^{2}$} & 0.75 & & 0.68 & & 0.64 & \\
\hline \multicolumn{3}{|c|}{ Return to scale } & 0.859 & & 1.213 & & 0.345 & \\
\hline
\end{tabular}

Note: * Significant at 5\% level, **Significant at 1\% level

Table.2 Cobb-Douglas production function for beans under different supply chains

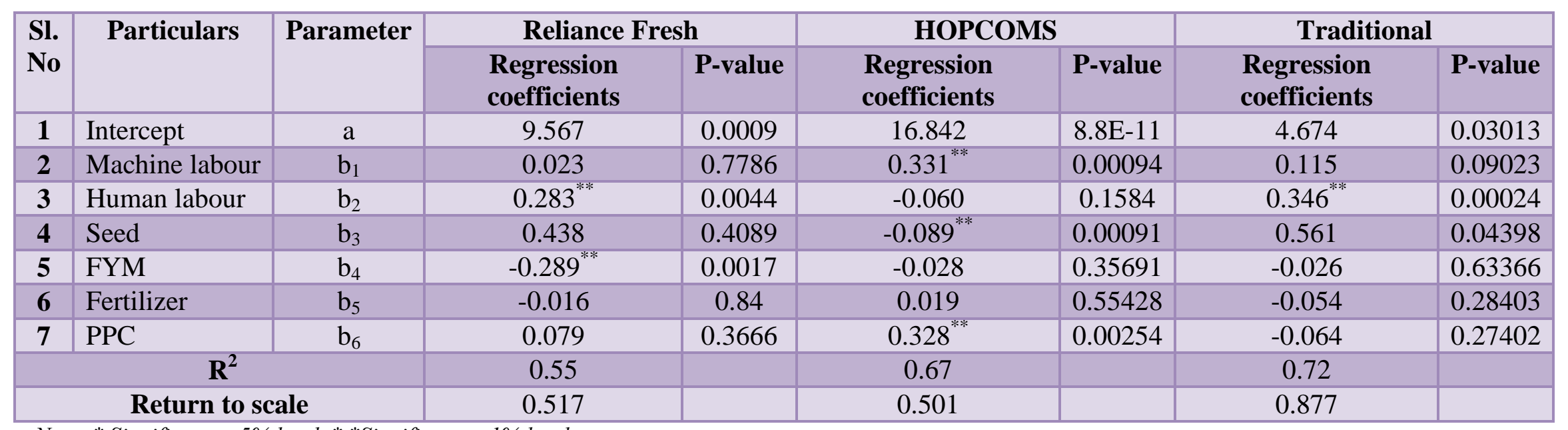

Note: * Significant at $5 \%$ level, * *Significant at $1 \%$ level 
The elasticity coefficients for human labour, seed and plant protection chemicals in HOPCOMS; were statistically significant at 5 per cent and 1 per cent level respectively.

The elasticity coefficients for seed and human labour in traditional marketing channel were statistically significant at 5 per cent and 1 per cent level respectively. The increase in resources like seed and FYM in Reliance fresh, machine labour and plant protection chemicals in HOPCOMS, machine labour in traditional marketing channel increases the gross returns, but not significantly.

The sum of elasticities was greater than unity for HOPCOMS, which shows increasing returns to scale and the sum of elasticities were less than unity for Reliance fresh and traditional marketing channel, which shows decreasing returns to scale.

Cobb-Douglas production function for beans under different supply chains

The regression coefficients of various resources of beans under different supply chains are presented in Table 2.

The production function analysis for beans under Reliance fresh, HOPCOMS and traditional marketing channel indicated that. 55, 67 and 72 per cent of the variation in gross returns was explained by the variables included in the production function respectively.

The elasticity coefficients for human labour and FYM in Reliance Fresh; were statistically significant at 1 per cent level; In other words, every one per cent increase in human labour, the gross returns could increase to the tune of 0.283 per cent. The elasticity coefficients for machine labour, seed and plant protection chemicals in HOPCOMS; were statistically significant at 1 per cent level respectively.
However one percent increase in seed will lead to decrease in gross returns by 0.089 per cent. Hence curtailing certain units of seed in the production process would increase the gross returns. The elasticity coefficients for human labour in traditional marketing channel were statistically significant at 1 per cent level respectively. The increase in resources like machine labour, seed and plant protection chemicals in Reliance fresh, fertilizer in HOPCOMS, machine labour and seed in traditional marketing channel increases the gross returns, but not significantly.

The elasticity coefficient for FYM and fertilizer in Reliance fresh, human labour seed and FYM in HOPCOMS, FYM, fertilizer and plant protection chemicals in traditional marketing channel were negative, indicating over utilization of these resource. Hence curtailing certain units of these resources in the production process would increase the gross returns. Goni et al., (2013) in their study on analysis of resource-use efficiency in dry season vegetable production in Jere, Borno State, Nigeria reported that farm inputs such as plant protection chemicals, fertilizer and human labour were over utilized.

The sum of elasticities was less than unity for Reliance fresh, HOPCOMS and traditional marketing channel, which showed decreasing returns to scale.

\section{Summary and Conclusion}

The production function analysis for tomato, the elasticity coefficient for human labour and fertilizer in Reliance fresh, FYM and fertilizer in HOPCOMS, FYM, fertilizer and plant protection chemicals in traditional marketing channel were negative, indicating over utilization of these resources. Hence curtailing certain units of these resources in the production process would increase the gross returns. The sum of elasticities was 
greater than unity for HOPCOMS, which shows increasing returns to scale and the sum of elasticities were less than unity for Reliance Fresh and traditional marketing channel, which shows decreasing returns to scale.

The production function analysis for beans, the elasticity coefficient for FYM and fertilizer in Reliance fresh, human labour seed and FYM in HOPCOMS, FYM, fertilizer and plant protection chemicals in traditional marketing channel were negative, indicating over utilization of these resources. Hence curtailing certain units of these resources in the production process would increase the gross returns. The sum of elasticities was less than unity for Reliance fresh, HOPCOMS and traditional marketing channel, which shows decreasing returns to scale. Efforts should be made through Raitha Samparka and Krishi
Vigyana Kendras to utilize farm resources rationally and to enhance productivity and profitability.

\section{References}

Directorate of Economics \& Statistics. 2017. State of Indian Agriculture. Ministry of Agriculture \& Farmers Welfare. Government of India.

Goni, M., Umar, A.S. and Usman, S. 2013. Analysis of Resource-Use Efficiency in Dry Season Vegetable Production in Jere, Borno State, Nigeria. Journal of Biology, Agriculture and Healthcare, 3(19): 45-50.

Heady, Earl O., and Dillon, John L. 1963. Agricultural production functions, Iowa State University Press, Ames, Iowa, p. 25.

\section{How to cite this article:}

Kiran, R. and Sivakumar, S.D. 2019. Resource use Efficiency of Major Vegetables in Different Supply Chains in Eastern Dry Zone of Karnataka, India. Int.J.Curr.Microbiol.App.Sci. 8(06): 2471-2476. doi: https://doi.org/10.20546/ijcmas.2019.806.295 